\title{
Hubungan Motif dan Kepuasan Penggunaan Media Sosial Instagram di Mahasiswa Komunikasi Penyiaran Islam Angkatan 2014-2017
}

\author{
Ngudi Ambar Sari ${ }^{1}$, Bukhari ${ }^{2}$, Usman ${ }^{3,}$ Prima Kurniati Hamzah \\ Universitas Islam Negeri Imam Bonjol Padang \\ ${ }^{1}$ Email : saringudiambar@gmail.com \\ 2Email : bukhari@uinib@gmail.com \\ ${ }^{3}$ Email : usmanma@gmail.com \\ ${ }^{4}$ Email: primakurniati@uinib.com
}

\begin{abstract}
Instagram is one of the most popular social media for the public. One difference between Instagram and other social media, is that instamam is more likely to be used to find information and share information with users than to interact directly with fellow users. The purpose of this study is to find out and explain the motives and active user satisfaction in using Instagram social media and find out the relationship between the motives and satisfaction of Instagram social media usage. This study uses use and gratification theory which assumes that individuals have certain goals in using media. The method used in this research is quantitative research methods. The data collection tool is the questionnaire has been validated. The research sample was 70 people. The sampling technique is simple random sampling. The statistic test that the researchers used was the Partial Correlation Test (Pearson Product Moment). Data is processed using SPSS version 20. The results of this study indicate users want to get information and knowledge that is happening at the present time. Information satisfaction becomes the most obtained by Instagram social media users. Overall Instagram social media has given satisfaction to users and there is a significant relationship between motives and satisfaction.
\end{abstract}

Keyword : motivation; satisfaction; communications

\section{ABSTRAK}

Instagram merupakan salah satu media sosial yang banyak diminati oleh khalayak. Salah satu perbedaan instagram dengan media sosial lainnya, dimana instgaram lebih cenderung digunakan untuk mencari informasi dan berbagi informasi kesesama pengguna dibandingkan berinteraksi langsung dengan sesama pengguna. Tujuan penelitian ini yaitu untuk mengetahui dan menjelaskan motif serta kepuasan pengguna aktif dalam menggunakan media sosial Instagram dan mengetahui hubungan antara motif dan kepuasan penggunaan media sosial instagram. Penelitian ini menggunakan teori use and gratification yang beranggapan bahwa individu memiliki tujuan tertentu dalam menggunakan media. Metode yang digunakan dalam penelitian ini adalah metode penelitian kuantitatif. Alat pengumpulan data adalah kuesioner telah divalidasi. Sampel penelitian berjumlah 70 orang. Teknik pengambilan sampel yaitu acak sederhana (simple random sampling). Uji Statistik yang peneliti gunakan adalah Uji Korelasi Parsial (Pearson Product Moment). Data diolah menggunakan SPSS versi 20. Hasil penelitian ini 
menunjukkan pengguna menginginkan untuk mendapatkan informasi dan pengetahuan yang terjadi pada saat sekarang ini. Kepuasan informasi menjadi paling banyak diperoleh oleh pengguna media sosial instagram. Secara keseluruhan media sosial instagram sudah memberikan kepuasan kepada pengguna dan terdapat hubungan yang signifikan antara motif dan kepuasan.

Kata Kunci : Motivasi; Kepuasaan; Instagram; Komunikasi

\section{PENDAHULUAN}

Komunikasi merupakan aspek terpenting dan kompleks bagi kehidupan manusia. Manusia sangat dipengaruhi oleh komunikasi yang dilakukannya dengan manusia lain, baik yang dikenal maupun yang tidak dikenal. Komunikasi tersebut bisa melalui media verbal dan nonverbal. Dosi Aprilinda Palewa, e-skripsi: "Motif Penggunaan dan Interaksi Sosial di Twitter (Studi Deskripti Kualitatif pada Mahasiswa Ilmu Komunikasi FISHUM UIN Sunan Kalijaga Yogyakarta)", (diakses pada tanggal 25 Februari 2019)

Perkembangan teknologi saat ini telah mempermudah aktivitas untuk berinteraksi. Pengiriman maupun penerimaan pesan dan informasi bisa dilakukan dengan menggunakan beragam media yakni audio, visual, audio visual, serta digital. Koran, radio, televisi bahkan komputer dan telepon genggam sebagai media jaringan internet kini telah mudah didapatkan.

Media sosial menjadi primadona baru dalam perkembangan media dunia. Media sosial atau akrab disebut jejaring sosial menyita perhatian masyarakat Indonesia, mahasiswa pada khususnya. Salah satu pertumbuhan media sosial yang cepat dikalangan masyarakat adalah instagram. Instagram adalah sebuah aplikasi berbagi foto yang memungkinkan pengguna mengambil foto, menerapkan filter digital, dan membagikannya ke berbagai layanan jejaring social, termasuk milik instgaram sendiri. Nur Rahmawati Khairah, e-Skripsi:"Motif Menggunakan Instagram Pada Mahasiswa UMY', (diakses tanggal 15 Maret 2018)
Media digunakan dengan motif yang berbeda-beda adanya 4 indikator yang mempengaruhi serbuah pembentukan motif yaitu, informasi, identitas pribadi, integrasi dan interaksi sosil, serta hiburan. Motif seseorang dalam menggunakan media tergantung tingkat kepuasan dan kegunaan dari media yang digunakan. Maka dari itu penyebab yang ada adalah lingkungan sosial dan psikologis yang dirasakan sebagai masalah dan media yang digunakan untuk menanggulangi masalah itu (pemenuh kebutuhan). Dyane Aulia Drestya, eskripsi:"Motif Menggunakan Social Media Path Pada Mahasiswa di Surabaya", (diakses tanggal 16Maret 2018)

Motif merupakan pengertian yang meliputi penggerak. Alasan-alasan atau dorongan-dorongan dalam diri manusia yang menyebabkan manusia itu berbuat sesuatu (Sobur, 2009: 266). Ada banyak motif penggunaan media yang mendorong seseorang menggunakan media. Mc Quail membagi motif penggunaan media kedalam empat kelompok, diantaranya motif informasi, motif identitas pribadi, motif integrasi dan interaksi sosial, motif hiburan (McQuail, 1991:72).

Pada dasarnya setiap individu mencari kepuasan tertentu dalam pemilihan media, salah satunya dalam penggunaan media sosial instagram. Kebutuhan atau pun keinginan individu berbeda-beda, begitu pula dengan kepuasan yang diperoleh. Khalayak cenderung akan meninggalkan media yang tidak sesuai dengan kebutuhan mereka. Widya Nastiti, "Hubungana Antara Motif dan Kepuasan Penonton terhadap Program Berita 
Islam Masa kini di Trans TV", (e-skripsi: diakses tanggal 5 Desember 2018)

Studi pendahuluan dilakukan pada mahasiswa KPI sebanyak 10 orang yang telah menggunakan Instagram 1 tahun. Studi pendahuluan ini menunjukkan bahwa motif terbanyak mahasiswa KPI dalam menggunakan instagram adalah motif informasi baik itu mengenai berita terbaru yang sedang ramai diperbicangkan maupun mencari-cari informasi tentang lowongan pekerjaan dan berbagai informasi yang berkaitan tentang hal penting lainnya seperti, mencari informasi tentang duina pendidikan, dunia politik, dan tempat-tempat terbaru yang sering dikunjungi orang banyak, serta mencari informasi dan berbagi infomrasi mengenai dakwah.

Sementara sisa lainnya menunujukkan behwa motif yang digunakan dalam penggunaan instagram adalah motif integrasi dan interaksi sosial, seperti ingin mengetahui keadaan teman, dan idola. motif hiburan, seperti ingin menghilangkan suntuk dari tugas-tugas dan mengisi waktu luang,dan yang terakhir sebagai motif identitas pribadi , seperti menjadikan instagram sebagai tempat berbagi untuk khalayak banyak.

Oleh sebab itu penelitian ini dilakukan untuk melihat bagaimana Hubungan antara Motif dan Kepuasan Penggunaan Media Sosial Instagram di Kalangan Mahasiswa Jurusan Komunikasi Penyiaran Islam Fakultas Dakwah dan Ilmu Komunikasi Angkatan 2014-2017.

\section{METODE PENELITIAN}

Model penenelitian ini yang penulis gunakan adalah pendekatan kuantitatif, karena pendekatan kuantitatif dapat menghasilkan data yang akurat setelah perhitungan yang tepat Salam dan Aripin, 2006: 13

Pendekatan kuantitatif bertujuan menggambarkan atau menjelaskansuatu masalah yang hasilnya dapat digeneralisasikan (Kriyantono, 2009: 55)
Populasi pada penelitian ini adalah mahasiswa jurusan Komunikasi Penyiaran Islam Fakultas Dakwah dan Ilmu Komunikasi UIN IB Padang angakatan 2014-2017 telah penggunaan Instagram minimal 1 (satu) tahun. Sampel penelitian berjumlah 79 orang (Bungin, 2006: 105)

Peneliti menggunakan teknik acak (pobability sampling) dengan cara sampling acak sederhana, (simple random sampling) yaitu teknik penarikan sampel dari populasi yang dilakukan secara acak, tanpa memperhatikan tingkatan strata yang dimilki populasi. Ani Ziadatus Syarifah, "Hubungana Antara Motif dan Kepuasan Penonton Pada Tayagan Drama Korea", (e-skripsi: diakses tanggal 5 Desember 2018)

Instrumen penelitian yang digunakan dalam penelitian ini ialah angket dan kuisioner. Data diolah menggunakan SPSS versi 20. Data dianalisi menggunakan uji korelasi dan uji regresi linear.

\section{HASIL DAN PEMBAHASAN}

1. Komponen dari variabel motif

\begin{tabular}{|c|c|l|c|c|}
\hline Variabel & No & Indikator & Mean & Rangking \\
\hline \multirow{6}{*}{ Motif } & 1 & $\begin{array}{l}\text { Motif } \\
\text { Informasi }\end{array}$ & $\mathbf{3 0 7 , 3}$ & $\mathbf{1}$ \\
\cline { 2 - 5 } & 2 & $\begin{array}{l}\text { Motif } \\
\text { Identitas } \\
\text { Pribadi }\end{array}$ & $\mathbf{2 9 3 , 4}$ & $\mathbf{2}$ \\
\cline { 2 - 5 } & \multirow{2}{*}{3} & $\begin{array}{l}\text { Motif } \\
\text { Integrasi } \\
\text { dan } \\
\text { Interaksi } \\
\text { Sosial }\end{array}$ & $\mathbf{2 7 3}$ & $\mathbf{3}$ \\
\cline { 2 - 5 } & 4 & $\begin{array}{l}\text { Motif } \\
\text { Hiburan }\end{array}$ & $\mathbf{2 6 2 , 7}$ & $\mathbf{4}$ \\
\hline
\end{tabular}

Tabel 1 Perolehan Skor Rata-Rata dari Variabel Motif

Dari tabel 1 diatas bahwa motif informasi menempati rangking 1 dengan perolehan skor rata-rata 307,3. Kemudian rangking 2 ditempati oleh motif identitas pribadi dengan perolehan skor rata-rata 293,4. Selain itu motif integrasi dan interaksi sosial berada di rangking 3 dengan perolehan skor rata-rata 273. Sedangkan motif hiburan berada di rangking 4 (terakhir) dengan 
perolehan skor rata-rata 262,7. Dengan kata lain, yang mendorong pengguna dalam menngunakan media sosial instagram adalah keinginan untuk mendapatkan atau memperoleh informasi, baik yang terjadi di lingkungan sekitar pengguna atau yang terjadi di dunia.

\section{Komponen dari Variabel Kepuasan}

\begin{tabular}{|c|c|l|c|c|}
\hline Variabel & No & Indikator & Mean & Rangking \\
\hline & 1 & $\begin{array}{l}\text { Kepuasan } \\
\text { Informasi }\end{array}$ & $\mathbf{3 0 7 , 6}$ & $\mathbf{1}$ \\
\cline { 2 - 5 } Kepuasan & 2 & $\begin{array}{l}\text { Kepuasan } \\
\text { Identitas } \\
\text { Pribadi }\end{array}$ & $\mathbf{2 9 6 , 5}$ & $\mathbf{3}$ \\
\cline { 2 - 5 } & 3 & $\begin{array}{l}\text { Kepuasan } \\
\text { Integrasi } \\
\text { dan } \\
\text { Interaksi } \\
\text { Sosial }\end{array}$ & $\mathbf{2 7 8 , 5}$ & $\mathbf{4}$ \\
\cline { 2 - 5 } & 4 & $\begin{array}{l}\text { Kepuasan } \\
\text { Hiburan }\end{array}$ & $\mathbf{2 9 8 , 7}$ & $\mathbf{2}$ \\
\hline
\end{tabular}

Tabel 2 Perolehan Skor Rata-Rata dari Variabel Kepuasaan

Tabel 2 diatas menyatakan bahwa kepuasan informasi menempati rangking 1 dengan perolehan skor rata-rata 307,6. Kemudian rangking 2 ditempati oleh kepuasan hiburan dengan perolehan skor rata-rata 298,7. Selain itu, kepuasan identitas pribadi berada di rangking 3 dengan perolehan skor rata-rata 296,5. Sedangkan kepuasan integrasi dan interaksi sosial berada di rangking 4 (terakhir) dengan perolehan skor rata-rata 278,5. Dengan kata lain, media sosial instagram telah berusaha memenuhi kebutuhan informasi para pengguna media sosial tersebut. Selain itu, media sosial instagram juga telah memenuhi fungsi salah satu media, yaitu memberi informasi.

\section{Korelasi hubungan motif dengan kepuasaan}

\begin{tabular}{|c|c|c|c|}
\hline No & Variabel & R Square & $\begin{array}{c}\text { Sig } \\
\text { Pvalue }\end{array}$ \\
\hline 1 & Motif Informasi & 0,774 & 0,000 \\
\hline
\end{tabular}

Tabel 3. Korelasi motif dengan kepuasaan

Dilihat dari tabel diatas terdapat hubungan antara variabel motif dengan kepuasaan dengan nilai p-value adalah 0,000 dan kekuatan kedua hubungan variabel ini adalah kuat 0,774 .

\section{KESIMPULAN}

Hasil penelitian memiliki beberapa kesimpulan diantaranya:

Motif yang paling dominan dimiliki oleh responden adalah motif informasi. Keinginan pengguna instagram untuk memenuhi kebutuhan informasinya lebih besar dibandingkan kebutuhan lainnya.

Kepuasan informasi menjadi yang paling banyak diperoleh oleh responden dan tidak adanya kesenjangan antara motif dan kepuasan.

Terdapat hubungan antara motif dan kepuasan yang signifikan dan memiliki korelasi menujukkan nilai yang positif. Hal tersebut menunjukkan semakin tinggi motif maka akan semakin tinggi juga kepuasan penggunaan media sosial instagram.

\section{DAFTAR KEPUSTAKAAN}

Al-Qur'an Departemen Agama RI.2003. Mushaf Al qur'an dan Terjemahannya. Jawa Barat: Cipta Bagus Segera)

Anggraeni Utomo, Dea. 2013. e-Jurnal:Motif Pengguna Jejaring Sosial Google+ di Indonesia.

Ardiyanto, dan Erdinaya.2005. Komunikasi Massa: Suatu Pengatntar,cetakan kedua. Simbiosa Rekatama Media: Bandunng.

Arikunto, Suharsini. 2002. Prosedur Penelitian. Jakarta: PT Rineka Cipta.

Aulia Drestya, Dyane. e-skripsi: Motif Menggunakan Social Media Path Pada Mahasiswa di Surabaya.

Ayu Puspitoroni, Dyah. e-Skripsi: Motif Dan Kepuasan Penggunaan Instagram (Studi Kesenjangan antara Motif dan Kepuasan Penggunaan Media Sosial Instagram pada Mahasiswa Unversitas Muhammadiyah Surakrta Angakatan 2013). 
Bungin, Burhan. 2006. Metodologi Penelitian Kuantitatif Komunikasi, ekonomi, Dan Kebijakan Publik Serta Ilmu-Ilmu Sosial Lainnya. Jakarta:Kencana.

Ghozali, Imam.. 2007. Aplikasi Analisis Multivariate dengan Progrma SPSS. Semarang: BPUNDIP.

Kriyantono, Rahmat. 2009. Teknik Praktis Riset Komunikasi. Jakarta: Kencana.

Kusuma Putri, Oriza. 2012. e-skripsi: Motif Remaja Dalam Menggunakan Media Jejaring Sosial Facebook (studi Deskriptif Tentang Motif Remaja Dalam Menggunakan Media Jejaring Sosial Facebook di Kota Mojokerto).

McQuail, Denis. 1991. Teori Komunikasi Massa Mcquail.Erlangga: Jakarta

Morissan. 2013. Teori Komunikasi. Ghalia Indonesia: Bogor.

Mulyadi, Mohammad. Penelitian Kuantitaif dan Kualitatif. Jakarta: Publica Institute.

Nastiti, Widya. e-skripsi: Hubungana Antara Motif dan Kepuasan Penonton terhadap Program Berita Islam Masa kini di Trans TV.

Nurudin. 2007. Pengantar Komunikasi Massa. Raja Grafindo Persada: Jakarta

Rahmah Alfafa I, Siti. 2017. e-skripsi: Motif Pengguna New Media (Studi Deskriptif Kuantitatif Pengguna Instagram di Kalangan Mahasiswa Fakultas Dakwah dan Komuniasi).

Rahmawati Khairah, Nur. e-Skripsi: Motif Menggunakan Instagram Pada Mahasiswa UMY.

Rakhmat, Jalaludin. 2007. Metode Penelitian Komunikasi. Bandung: Rosdakarya.

Salam, Syamsir., MS., Jaenal Aripin. 2006. Metodologi Penelitian Sosial. Jakarta: UIN Jakarta Press.

Santoso, Singgih. 1999. SPSS: Mengolah Data Statistik Secara Profesional. Jakarta: PT Elex Multi Komputindo.

Sobur, Alex . 2009. Psikologi Umum: Dalam Lintasan Sejarah. Bandung:Pustaka Setia.
Subgayo, Pangestu., dan Djarwanto Ps. 2005. Statislka Induktif. Yogyakarta: BPFEYpgyakarta.

Sugeng Cahyono,Anang. e- Jurnal: Pengaruh Media Sosial Terhadap Perubahan Sosial Masyarakat di Indonesia",

Sugiyono. 2012. Metode Penelitian Kunatitatif, Kualitatif, Dan R\&D. Bandung: ALFABETA.

Tim Pusat Humas Kementerian Perdagangan RI. 2014. Panduan Optimalisasi Media Sosial Untuk Kementerian Perdagangan RI. Kemendagri RI: Jakarta.

Wahyuni, Isti Nursih. 2014. Komunikasi Massa. Graha Ilmu: Yogyakarta.

West, Richard and Lynn H. Turner.2010. Pengantar Teori Komunikasi : Analisis dan Aplikasi.Jakarta: Salemba Humanika.

Yafi Aljawiy, Abdillah. e-journal Jurusan Sitem Informasi Fakultas Teknologi Informasi: Jejaring Sosial dan Dampak Bagi Penggunanya. Surabaya: Institut Teknologi Sepuluh Nopember.

Yamin, Sofyan., dan Heri Kurniawan. 2014. Teknik Analisis Terlengkap dalam Sotfware SPSS edisi 2. Jakarta: Selemba Infotek.

Yen Pangesti, Yeni. e-Skripsi: Dampak Media Soial Terhadap Pola Komunikasi Anak Dalam Pembentukan Karakter Sopan Santun di Sekolah Dasar".

Ziadatus Syarifah, Ani. e-skripsi: Hubungana Antara Motif dan Kepuasan Penonton Pada Tayagan Drama Kore 